\title{
Regionalism and its Diverse Framings in German-speaking Europe Across the Long Twentieth-Century
}

\author{
Jeremy DeWaal
}

\section{Introduction}

In the 1950s, a German regionalist from the city of Lübeck, reflecting on the plight of German expellees, wrote on how being forced out of one's regional place of home was to be made into an 'only German,' a term that sounded 'uncanny' to his ears. They must never, he argued, abandon the regionalist and federalist ideas. ${ }^{1}$ The passage reflected a notion of Germanness as defined by regional diversity-an idea popularized by the 'Heimat movement' around the turn of the century. The idea of 'Heimat' referred to a sense of belonging and cultural uniqueness within local and regional places that could be extended abstractly to the nation at large. The concept proved central to German, Austrian, and Swiss regionalisms, which promoted regional cultural particularities through 'Heimat books,' 'Heimat journals,' 'Heimat festivals,' and diverse 'Heimat traditions.' While this chapter focuses primarily on regionalism in Germany, the question of ethnically-mixed regions, contested borderlands, shifting national borders, and violent struggle over who and what regions belonged to the nation render a broader purview of German-speaking Europe useful. At different times, millions of ethnic German regionalists lived either outside Germany or, particularly in the latter half of the century, within a German nation-state but outside of regions from which they had been expelled. A broader purview on German-speaking Europe, meanwhile, allows for comparative consideration of examples from neighbouring Austria and Switzerland, which demonstrate both parallel and divergent developments.

The political framings of regionalism in German-speaking Europe were diverse. In Germany alone, this could be seen in the procession of regionalism through the different political systems across the century. Cultural regionalism found appeal amongst conservatives, liberals, and social democrats, as well as among urban and rural citizens, and particularly came to the fore at moments of crisis and change. Following its popularization in the Second Empire and its evolution in the interwar years, the Nazi regime appropriated key aspects of regionalism for propaganda while simultaneously displaying ambivalence toward the movement. After 1945, amidst national defeat, mass dislocation and destruction, regional places of home emerged as sites of preoccupation. While the communist dictatorship in the East illustrated ambivalence toward regionalism, in the early Federal Republic, it came to the fore as a source of flexible identities that offered a site of engagement with federalism, democracy and ideas of European unification. Expellee desires for lost

${ }^{1}$. .....nur noch Deutsche," Vaterstädtische Blätter 7, no.12 (December 1956): 4. 
regions, meanwhile, became intertwined in Cold War conflict, partly informing later debates over the 'intrinsic' political meaning of regionalism.

Conceptions of the relationship between region and nation proved equally flexible and diverse. In theory, the relationship of region to nation could range from separatism on one end and to nationalist affirmation on the other and anywhere in between. ${ }^{2}$ Limited examples of both separatism and unitary nationalism could be found in Germany and Austria, though notions of regionalism as dovetailing with nation-building proved dominant. This understanding, however, differed internally from the nationalist-affirming regionalism that dominated in the first half of the twentieth century to the post-war notion of regional Heimat as de-centring, restraining, and therein serving a new German national idea. M eanwhile, in Austria, different groups at varying times framed regionalism as strengthening loyalty to the Habsburg Empire, dovetailing with pan-German visions, or cementing Austrian distinctiveness, the latter of which dominated after 1945.

The history of regionalism in Germany, Austria, Switzerland, and other German-speaking areas were certainly not without their unique national inflections. National uniqueness could be found, among other places, in the role of German regionalism in imagining a post-war German federalism or in distancing the post-1945 Austrian national idea from a German one. At the same time many of the underlying forces of the movement across the twentieth century had a broader European provenance with parallels in other national contexts.

\section{Modernity, Popular Regionalism, and the Nation}

In the mid nineteenth century, the founder of German Folklore Studies, Wilhelm Heinrich Riehl proclaimed that the uniqueness of German culture could be found in its regional cultural diversity that could only be discovered by wandering through its diverse landscapes. ${ }^{3}$ By the end of the century, regionalism had emerged as a popular movement. The movement was certainly a modern phenomenon, though much diversity in regional cultural practices and dialects stemmed from century-long histories of territorial fragmentation. Looking as far back as the early medieval period, the settlement patterns of Germanic tribes or 'Stämme' were reflected in important modern German dialect borders (Figure 1), while, throughout the early modern period, the Holy Roman

\footnotetext{
${ }^{2}$ Joost Augusteijn and Eric Storm, eds., Region and State in Nineteenth-Century Europe: Nation-Building, Regional Identities and Separatism (Basingstroke: Palgrave Macmillan, 2012); Philipp Ther and Holm Sundhaussen, eds., Regionale Bewegungen und Regionalismen in europäischen Zwischenräumen seit der Mitte des 19. Jahrhunderts (Marburg: Herder Institut, 2003); Peter Haslinger, ed., Regionale und nationale Identitäten. Wechselwirkungen und Spannungsfelder im Zeitalter moderner Staatlichkeit (Würzburg: Ergon, 2000).

${ }^{3}$ Wilhelm Heinrich Riehl, The Natural History of the German People, trans. David Diephouse (Lewiston, NY: Edwin Mellen Press, 1990).
} 
Empire functioned as an 'incubator' that preserved territorial diversity. ${ }^{4}$ The number of states would only be reduced first with the Napoleonic conquest, which forged sixteen expanded client states, followed by the German Confederation, consisting of thirty-nine states.

While earlier studies of nationalism assumed that nations overwrote 'pre-modern' regional identifications, scholars over the past several decades have shown that regional identities were not pre-modern at all, but rather a product of modernity that emerged hand-in-hand with nationalism. As David Blackbourn and James Retallack have further pointed out, local spaces were by no means more narrow-minded than national ones, nor did all modern dynamism come from the top. ${ }^{5}$ The idea of Heimat as referring to rootedness in local and regional places was itself modern, with the word in previous centuries referring only to a legal right of settlement and inheritance. ${ }^{6}$ The mindset of regionalism, like nationalism, relied on new ideas about selfhood, identity, and space, the seeds of which emerged in romanticism. The romantics were the first to evoke a notion of Heimat as about a subjective experience of space, with the binary of foreignness and the nearness of home representing a salient theme. ${ }^{7}$ By mid-century, educated elites like Riehl took a growing interest in regional histories and cultural uniqueness, with the first regional Heimat and history journals emerging. Regional folklore studies, begun by educated elites, emerged as the scholarly arm of subsequent regionalist movements in Germany and throughout Europe. ${ }^{8}$ While 'Heimat' could also refer to domestic places of home, localities, and, more abstractly, the nation at large, it emerged as a central concept evoked by regional cultural societies.

The forces of modernity, far from sweeping away focus on region, increased it exponentially. Filtering out the specific factors of modernization that 'triggered' regionalist movements is rendered problematic by the fact that they emerged fairly simultaneously throughout Western Europe while processes of modernization remained territorially uneven. ${ }^{9}$ At the same time, the aggregate forces of modernization and urbanization proved crucial to sparking the modern regionalist movement by the end of the nineteenth century. In Germany, the decades from 1870 to 1914 saw not only the emergence of a new unified nation, but also unprecedented levels of industrialization, urbanization, and population movement that changed local and regional landscapes. During this period, the German population grew by over $58 \%$, while inner-migration resulted in nearly half no longer living

\footnotetext{
${ }^{4}$ M ack Walker, German Home Towns: Community, State and General Estate 1648-1871 (Ithaca: Cornell University Press, 1971).

${ }^{5}$ David Blackbourn and James Retallack, 'Introduction', in Localism, Landscape, and the Ambiguities of Place: German-Speaking Central Europe, 1860-1930, eds. David Blackbourn and James Retallack (Toronto: University of Toronto Press, 2007), 15-16.

${ }^{6}$ Hermann Bausinger, 'Heimat in einer offenen Gesellschaft', in Die Ohnmacht der Gefühle, ed. Jochen Kelter (Weingarten: Drumlin, 1986), 93-94.

${ }^{7}$ Nigel Reeves, 'Heimat aus der Ferne', in Heimat im Wort, ed., Rüdiger Görner (Munich: Iudicium, 1992), 72.

${ }^{8}$ See the chapter by Hopkin.

${ }^{9}$ See the chapter by Storm
} 
in the town of their birth by the turn of the century. ${ }^{10}$ Urbanization during the Second Empire exploded, with the number of Germans living in cities rising from $36 \%$ to $60 \%$. ${ }^{11}$ Fast-paced industrial growth reshaped everyday life at an unprecedented rate, while technologies of communication and travel increased mobility and brought the outside into local and regional worlds like never before.

Rapid changes and the imperatives of nation-building both informed popular regionalism and interest in 'place-making.' ${ }^{12}$ The regionalist movement encompassed a wide array of media, ranging from art, architecture, literature, music, protection of dialect, and theatre to engagement in 'Heimatschutz,' which focused on protecting environmental landscapes and cultural heritage sites. Regionalist activities thrived in new Heimat societies, regional history associations, singing and hiking groups, local 'beautification societies' and a range of 'Heimat journals' and 'Heimat books' aimed at a popular audience. While the educated middle class represented the backbone of the movement, it enjoyed both support from above and a relatively receptive audience from below. The actors who shaped ideas of region, moreover, included not only natives but also many from the outside. ${ }^{13}$ Regionalist societies were rarely associated with a political party or interest group, emphasizing instead community cohesion over the social fracture churned up by processes of modernization. This appeal to regionalism to bridge across partisanships also had parallels in other national contexts. ${ }^{14}$

Despite the diversity of regional cultural practices that predated modern regionalism, modern regionalist movements did not simply 'discover' a defined regional substance just lurking beneath the surface. ${ }^{15}$ Even the notion of what territorial spaces corresponded to a common region remained tremendously fluid and contested. Though often using the language of preservation, the birth of regionalism involved significant processes of invention and reinvention of tradition.

Regionalists quickly co-opted and therein radically transformed pre-existing local practices, including agricultural events and city markets that were reinvented into celebrations of local and regional community. The Cannstatter festival, Bavarian Oktoberfest and the Bremer Freimarkt offered only a few examples of the phenomenon, invented or appropriated to bolster identification with Württemberg, Bavaria, and Bremen, respectively. Sharpshooter festivals ( Schützenfeste), once serving a functional defence purpose in centuries past, were often co-opted as celebrations of both regional and national communities. Appropriation of Carnival as an expression of regional identity in

\footnotetext{
${ }^{10}$ Hans-Ulrich Wehler, Deutsche Gesellschaftsgeschichte: Von der 'Deutschen Doppelrevolution' bis zum Beginn des Ersten Weltkrieges, vol.3 (M unich: Beck, 2008), 493-510.

${ }^{11} \mathrm{lbid}, 512$.

${ }^{12}$ On industrialization and urbanization generating interest in regional culture, see Hermann Bausinger, Folk Culture in a World of Technology, trans. Elke Dettmer (Bloomington: Indiana University Press, 1990).

${ }^{13}$ Eric Storm, The Culture of Regionalism: Art, Architecture and International Exhibitions in France, Germany and Spain, 1890-1939 (M anchester: M anchester University Press, 2010).

${ }^{14}$ See the chapter by Molina and Núñez Seixas.

${ }^{15}$ Storm, Culture of Regionalism.
} 
the Rhineland represented a particularly salient case of how regionalists reinvented tradition. No longer the late medieval festival symbolizing the sinfulness of man to be overcome on Ash Wednesday, modern Carnival in the Rhineland was reformulated as a positive celebration of local and regional identities. ${ }^{16}$ Dialect became the primary language of such traditions, marshalled to underscore their function as pillars of regional identity.

Turn-of-the-century regionalists included diverse actors both urban and rural and from divergent political groups. Leading regionalists like Paul Schultze-Naumburg or Hermann Löns represented clear examples of nationalist conservative regionalism, often accompanied by antiurbanism and scepticism of democracy. Amongst liberal groups, the participatory nature of regionalism and its contrast with the culture of elites both made it attractive. As Celia Applegate has pointed out in a study of the Palatinate, regionalism often included a 'democratization of public life' and a reaction against processes of centralization. ${ }^{17}$ Regionalism also emerged as an important node of environmental protection in German-speaking Europe and in the regionalist movements of Western Europe more broadly. ${ }^{18}$ Regionalism was not invariably ruralist, though anti-urbanism could certainly be found in a number of Heimat novels and artistic works. ${ }^{19}$ Others perceived regionalism as compatible with both urban life and cosmopolitanism. ${ }^{20}$ As M aiken Umbach and Bernd Hüppauf have pointed out, fostering regionalism and Heimat in urban architecture often represented not anti-modernism but rather a search for a 'vernacular modernism. ' ${ }^{21}$ Urbanites proved particularly prominent regionalists, and, though sometimes indulging in romantic desires for the provinces, also viewed cities as sites of Heimat. As the Dresden musician, Hugo Jüngst, asked rhetorically in 1902: 'Do we love our Heimat less, because we grew up on the cobblestones of a large city?' Urbanites, he believed, held just as much to their regional cultural particularities as rural inhabitants and should feel equal rights to draw on Heimat in art. ${ }^{22}$

\footnotetext{
${ }^{16}$ Jeremy DeWaal, 'The Reinvention of Tradition: Form, M eaning, and Local Identity in M odern Cologne Carnival', Central European History 46 (2013): 495-532.

${ }^{17}$ Celia Applegate, A Nation of Provincials: The German Idea of Heimat (Berkeley: University of California Press, 1990), 62. See also, Alon Confino, The Nation as a Local Metaphor: Württemberg, Imperial Germany, and National M emory, 1871-1918 (Chapel Hill: University of North Carolina Press, 1997); Eric Kurlander, 'The Landscapes of Liberalism: Particularism and Progressive Politics in Two Borderland Regions', in Localism, eds., Blackbourn and Retallack, 124-145.

${ }^{18}$ William Rollins, A Greener Vision of Home: Cultural Politics and Environmental Reform in the German Heimatschutz M ovement, 1904-1918 (Ann Arbor: University of M ichigan Press, 1997). See also chapter by Meyer.

${ }^{19}$ Karlheinz Rossbacher, Heimatkunstbewegung und Heimatroman (Stuttgart: Ernst Klett, 1977).

${ }^{20}$ On the regional art movement throughout Europe, see Storm, Culture of Regionalism; On Heimat art and urban culture, see Jennifer Jenkins, Provincial M odernity: Local Culture and Liberal Politics in Fin-de-Siècle Hamburg (Ithaca: Cornell University Press, 2003).

${ }^{21}$ M aiken Umbach and Bernd-Rüdiger Hüppauf, eds., Vernacular M odernism: Heimat, Globalization and the Built Environment (Stanford: Stanford University Press, 2005).

${ }^{22}$ Hugo Jüngst, 'Los von Berlin', in Heimat deine Heimat, ed., Jürgen Liebing (Darmstadt: Luchterhand, 1982), 39.
} 
Among the forces that fuelled regionalism, the emergence of modern nation-states proved crucial. Regionalists in the German Empire overwhelmingly emphasized regionalism as reinforcing the nation idea, while the Heimat concept, as Applegate points out, came to the fore as a mediator between the immediate spheres of local life and a broader national idea. ${ }^{23}$ Such notions of national unity in regional diversity were not limited to Germany. they also played a role, at least to some, degree in national integration in Britain, Italy, and France, among others. ${ }^{24}$ The German Empire was unique perhaps only in the extent to which it relied on ideas of national unity as based on regional diversity-arguably outstripped in Europe only by neighbouring Switzerland, whose poly-ethnic cantons fundamentally relied on a strong idea of unity within regional diversity. ${ }^{25}$ M eanwhile, within the multi-ethnic Austro-Hungarian Empire, most ethnic-Germans and some Austrians of other ethnicities saw regionalism and loyalty to the Empire as harmonious, while some non-ethnic German regionalisms in the Empire challenged loyalty to the state. ${ }^{26}$

Within Germany, ideas of nation as rooted in regional diversity were never entirely uncontested. Prior to national unification, early nationalists, such as Ernst M oritz Arndt argued in his famous citation that the 'Fatherland,' must be bigger than Swabia or the Rhineland, while Borussian historians often cast national unification as about transcending region. What could be seen from one perspective as regional-national harmony or Heimat as binding region and nation, could from another, be smeared as 'Kleinstaaterei' (petty statism). Even in neighbouring Switzerland, critics of excessive decentralization criticised what they saw as a 'Kantönligeist' (small canton spirit). ${ }^{27}$ Yet, by the turn of the century, national unity and regional diversity in the German empire were popularly seen as complimentary. The federalist structure of the state reinforced such understandings on the political level, though it was dominated by Prussia, by far the largest state. Regional state building that began prior to national unification continued in the Wilhelmine years. Such state building in realms of education, infrastructure, as well as the promotion of regional festivals, museums and historical societies often promoted simultaneous identification with region and nation. ${ }^{28}$

\footnotetext{
${ }^{23}$ On Heimat as a mediating point, see Applegate, Nation of Provincials. Alon Confino in a different approach argues for Heimat as a local metaphor of nation. See Confino, Nation as a Local M etaphor.

${ }^{24}$ Stefan Cavazza 'Regionalism in Italy: A Critique', in Region and State, eds., Augusteijn and Storm, 69-89; Timothy Baycroft, 'National Diversity, Regionalism and Decentralism in France', in Ibid, 57-68; Robert Colls, 'Gaelic and Northumbrian: Separatism and Regionalism in the United Kingdom, 1890-1920', in ibid, 172-191. See also the chapter by Molina and Núñez Seixas.

${ }^{25}$ Oliver Zimmer, A Contested Nation: History, M emory and Nationalism in Switzerland, 1761-1891 (Cambridge: Cambridge University Press, 2003).

${ }^{26}$ Peter Haslinger, 'How to Run a M ultilingual Society: Statehood, Administration and Regional Dynamics in Austria-Hungary, 1867-1914', in Region and State, eds., Augusteijn and Storm, 111-128.

27 Zimmer, A Contested Nation.

${ }^{28}$ Abigail Green, Fatherlands: State-Building and Nationhood in Nineteenth-Century Germany (Cambridge: Cambridge University Press, 2001); and Siegfried Weichlein, Nation und Region: Integrationsprozesse im Bismarckreich (Düsseldorf: Droste, 2004).
} 
Harmonizing the two, however, did mean forgetting histories of conflict. Forgetting how states such as Württemberg sided with the Habsburg Empire in the Austro-Prussian war, as Alon Confino points out, proved a case in point. ${ }^{29}$

In national borderlands and ethnically-mixed regions, the relation between region and nation became a particularly pressing question. Ethnic German border regions were often among the most vocal in emphasizing their region's Germanness, a trend visible in Heimat literature. ${ }^{30}$ The notion of the Rhineland as a 'Watch on the Rhine' that protected the nation from French encroachment, was a clear example. This phenomenon can be seen in other national contexts, as Bassin and Suslov point out for the case of Russia. ${ }^{31}$ Ethnically-mixed regions often proved surprisingly resilient. Though they often succumbed to the pressure of nationalist movements, historians have increasingly challenged the inevitability of the phenomenon. ${ }^{32}$ In places like Bohemia, by the turn of the century, nationalization increasingly overtook multi-ethnic local and regional ideas-a phenomenon with parallels elsewhere in Europe. ${ }^{33}$ In the ever-contested territory of Alsace national struggle between France and Germany did much to shape the very notion of Alsace as a region. While outsiders sought to influence Alsatian ideas of region, Alsatians themselves used it to negotiate their position within the German Empire. ${ }^{34}$ M eanwhile, regional tourism emerged as a nationalizing force in border regions. ${ }^{35}$

While growing nationalism brought border regions under increasing pressure, the outbreak of the First World War would represent an inflection point in twentieth-century regionalism more broadly. Though regionalists had generally not been militaristic in tone, they were forced to adapt to a wartime footing. While stopping many activities, Heimat enthusiasts channelled others into addressing sagging morale and keeping soldiers in the field connected to their Heimat. ${ }^{36}$ The state, meanwhile, used Heimat tropes to mobilize regional energies. ${ }^{37} \mathrm{~A}$ telling practice could be found in

\footnotetext{
${ }^{29}$ Confino, Nation as a Local M etaphor.

${ }^{30}$ Andreas Schumann, Heimat denken: Regionales Bewusstsein in der deutschsprachigen Literatur zwischen 1815 und 1914 (Cologne: Böhlau, 2002).

${ }^{31}$ See chapter by Bassin and Suslov.

32 See James Bjork, Neither German nor Pole: Catholicism and National Indifference in a Central European Borderland (Ann Arbor: University of Michigan Press, 2008).

${ }^{33}$ Jeremy King, Budweisers into Czechs and Germans: A Local History of Bohemian Politics, 1848-1948 (Princeton: Princeton University Press, 2005); Peter Sahlins, Boundaries: The Making of France and Spain in the Pyrenees (Berkeley: University of California Press, 1989).

${ }^{34}$ Daniel M ollenhauer, '“Aufgepfropftes Franzosentum auf deutschen Stamm": Der elsässiche Volkscharakter in der deutschen Elsaß-Publizistik', in Regionale und Nationale Identitäten, ed., Haslinger, 95-112; Christopher Fischer, Alsace to the Alsatians?: Visions and Divisions of Alsatian Regionalism, 1870-1939 (New York: Berghahn, 2010).

${ }^{35}$ Pieter Judson, 'Tourismus, Nationalisierung der Landschaft und lokales Identitätsmanagement um die J ahrhundertwende: Böhmen, die Steiermark und Trentino/Südtirol' in Regionale und Nationale Identitäten, ed., Haslinger, 112-128.

${ }^{36}$ Applegate, Nation of Provincials, 108-120.

${ }^{37}$ Confino, Nation as a Local M etaphor, 165-169, 184-185, 194-200.
} 
the creation of wooden sculptures of regional historical figures, with buyers of war loans each driving a nail into the sculpture-a process that covered the regionalist figure in a sheet of armoursymbolically linking the region and the nation in a common endeavour. ${ }^{38}$ After the defeat of the First World War, largely seen as a moment of national humiliation in Germany and Austria, regionalism would continue to evolve through the tumultuous interwar years and the creation of new democratic states.

\section{From Democracy to Dictatorship}

$M$ any of the challenges that faced the new infant democracies reshaped the regionalist movement. Weimar Germany had lost a number of its former regions, with the greatest losses to the East in Posen, West Prussian, and Upper Silesia, as well as in Alsace-Lorraine and slivers of the Rhineland to the West and parts of Schleswig to the North. Meanwhile, the Rhineland was occupied by the allies, while the Saarland was placed under the League of Nations. Former German regions that became part of new nation-states often found their national loyalties a matter of suspicion. ${ }^{39}$ In the Alsace, French assimilation politics reduced the initial receptivity of many Alsatians to French rule, who used regionalism to defend, among other things, the use of German in schools. ${ }^{40} \mathrm{M}$ any ethnic Germans in regions transferred to Poland moved to Germany, while those who remained presented a notable problem for the new Polish state. Germans in Poland remained a diverse group whose attraction to German nationalism varied, fracturing particularly according to their previous belonging to the German, Austrian, or Russian state. ${ }^{41}$ Those who relocated to Germany developed new methods to promote their native regional cultures. 'City-sponsorships' ( Patenschaften)-institutions that would gain more prominence after 1945-emerged first in the Weimar Republic. Such sponsorships, like that of M annheim for the Memelland in 1929 offered a common geographic centre for regional cultural preservation. ${ }^{42}$

Regionalism in Austria was similarly jolted by the collapse of the Habsburg Empire, territorial reconfiguration, and the establishment of a new republic. The Austrian Republic was symbolically constituted by the declaration of accession of its regional states, while the loss of the Empire triggered a national identity crisis. The stability of regional identities in time of change made

\footnotetext{
${ }^{38}$ Gerhard Schneider, 'Zur M obilisierung der "Heimatfront": Das Nageln sogenannter Kriegswahrzeichen im Ersten Weltkrieg', Zeitschrift für Volkskunde 95 (1999): 32-62.

${ }^{39}$ Philipp Ther, 'Einleitung: Sprachliche, kulturelle und ethnische "Zwischenräume" als Zugang zu einer transnationalen Geschichte Europas', in Regionale Bewegungen, eds., Ther and Sundhausen, xix.

${ }^{40}$ Christiane Kohser-Spohn, 'Der Traum von gemeinsamen Europa. Autonomiebewegungen und Regionalismus im Elsaß, 1870-1970', in Regionale Bewegungen, eds., Ther and Sundhaussen, 89-111.

${ }^{41}$ Winson Chu, The German Minority in Interwar Poland (Cambridge: Cambridge University Press, 2012).

42 Bundesarchiv, B 234/626, 'Patenschaften--Brücken zur alten Heimat: M annheim erneuerte seine

Patenschaft für das Memelland', Badische Neueste Nachrichten, August 14, 1953.
} 
regionalism a clear asset, though the interwar years also saw shifting ideas of the relationship between region and nation. Struggle to accept visions of a small-state Austria informed an uptick in desires for unification with a greater Germany that could be found across multiple political groups. ${ }^{43}$ This could particularly be seen in Tirol, whose southern half was ceded to Italy. While Tirolian regionalists had long viewed region, German ethnicity, and Habsburg loyalties as harmonious, after 1918 Tirolian desires for unification with Germany grew exponentially. ${ }^{44}$ Other Austrian regionalists promoted a distinct notion of Austrian national identity within a new federalist republic. Though the new Austrian republic maintained more centralist elements than neighbouring Germany, regional 'Landeshauptmänner' (regional state presidents) played a significant role in political administration.

While in arts and architecture, Heimat art partially gave way to new styles, the interwar years reveal tremendous growth in lay interest in regionalism in a number of fields. The political instability, social fracture, and economic uncertainty that defined the interwar years fuelled popular desires for a more stable, cohesive and secure world within a familiar regional landscape. Publication of Heimat journals in Germany grew exponentially, while Heimatkunde emerged as a school subject in a major way. Rather than advocating a narrow focus on the regional world, theorists of the subject often aimed to foster a broader sense of citizenship. While some advocates of the subject reflected a penchant for rural idealism, Heimatkunde found success in both urban and regional contexts and amongst both conservative and liberals. ${ }^{45}$

The political diversity of regionalism and its harmony with nation-building continued in the Weimar Republic. The federalist Weimar constitution reaffirmed the idea of Germany as a nation of diverse regions, declaring the German people to be a united group of regional ' Stämme' (tribes). Improving the federalist system remained a tremendous preoccupation of reformers. (Figure 2) Those like Hugo Preuß argued that national unity could only be preserved by emphasizing regional diversity through a balanced federalist system, with regions acting as critical sites of citizenship and political participation. ${ }^{46}$ Heimat was also viewed as a site of unity above the fray of partisan conflicts that harangued the Republic.

Weimar regionalism was most influenced by the growth of nationalism, though minor separatist movements emerged in the early years, particularly along the western border where it

\footnotetext{
${ }^{43}$ Gerald Stourzh, Vom Reich zur Republik. Studien zum Österreichbewusstsein im 20. Jahrhundert (Vienna: Wiener Journal Zeitschriftenverlag, 1990).

${ }^{44}$ Laurence Cole, 'The Construction of German Identity in Tirol, 1848-1945', in Regionale Bewegungen, eds., Ther and Sundhaussen, 20.

${ }^{45}$ Eduard Spranger, 'Das Bildungswert der Heimatkunde' (1923), in Eduard Spranger, Gesammelte Schriften II: Philosophische Pädagogik (Heidelberg: Quelle \& Meyer, 1975), 294-319.

${ }^{46}$ Hugo Preuß, Reich und Länder (Berlin: Carl Heymanns, 1928), 21, 157; Celia Applegate, 'Democracy or Reaction?: The Political Implication of Localist Ideas in Wilhelmine and Weimar Germany', in Elections, Mass Politics, and Social Change in M odern German, eds., James Retallack and Larry Eugene Jones (Cambridge: Cambridge University Press, 1992), 247-266.
} 
enjoyed French support. Rhenish separatists attempted to declare an independent 'Rhenish Republic' in 1919 and again during the French occupation of the Ruhr in 1923, while groups of Upper Silesians, facing a plebiscite on their national belonging, indulged in separatist imaginings of an independent state. The Austrian state faced separatist challenges in the Vorarlberg which sought to unify with neighbouring Switzerland. Separatist movements, however, often struggled to gain traction, among other reasons because of their inability to marshal the same political promises of nation along with the vagueness of what constituted the region itself. ${ }^{47} \mathrm{As}$ the Weimar writer on the idea of Heimat, Kurt Stavenhagen noted, while the constitution declared Germans to be a unified group of 'Stämme' no one knew precisely what or where they were-a reference to divergent imaginings of what places and groups constituted a regional people. ${ }^{48}$ The growing convergence of regionalist and nationalist language proved more prominent, with many viewing the nation as under threat by the punitive Versailles settlement, economic disaster, and foreign incursions and occupation. ${ }^{49}$ Regionalists proved susceptible to the idea of an assertive nation as a source of redemption, while, as Peter Fritzsche has argued, many Weimar citizens confronted their challenges by projecting their fate onto the surface screen of the nation. ${ }^{50}$

The Nazi seizure of power in 1933 brought both change and strategic ideological appropriation of the language of regionalism. While at least one recent work has argued for a strong relationship between regionalism and Nazi ideology, much evidence points to the regime's ambivalent and divergent approach toward regionalism. ${ }^{51}$ Nazi ideology, as Lutz Raphael points out, was in many realms not crisply defined, containing areas of plurality and contradiction, an observation that could be easily applied to its engagement with regionalism. ${ }^{52}$ The divergent attitudes of the regime toward regionalism can be seen by moving beyond institutional analysis to the realm of cultural geography. ${ }^{53}$ Though the regime selectively appropriated regionalism in

\footnotetext{
${ }^{47}$ See Peter Haslinger, 'Nationalismus und Regionalismus: Konflikt oder Koexistenz?', in Ther and Sundhausen, eds., 267-274.

${ }^{48}$ Kurt Stavenhagen, Heimat als Lebenssinn, 2nd ed. (Göttingen: Vandenhoeck \& Ruprecht, 1948), 49-50.

${ }^{49}$ Celia Applegate, 'The Question of Heimat in the Weimar Republic', New Formations 17 (1992): 64-74.

50 Peter Fritzsche, 'Cities Forget, Nations Remember', in Pain and Prosperity: Reconsidering Twentieth-Century German History, eds., Paul Betts and Greg Eghigian (Stanford: Stanford University Press, 2003), 35-59.

${ }^{51}$ See M aiken Umbach and Claus-Christian Szejnmann, eds., Heimat, Region, and Empire: Spatial Identities under National Socialism (Basingstoke: Palgrave Macmillan, 2012) and Thomas Schaarschmidt, Regionalkultur und Diktatur: Sächsische Heimatbewegung und Heimat-Propaganda im Dritten Reich und in der SBZ/DDR (Cologne: Böhlau, 2004). See also M aiken Umbach and Xosé-M anoel Núñez, 'Hijacked Heimats: National Appropriation of Local and Regional Identities in Germany and Spain, 1930-1945,' European Review of History 15, No.3 (2008): 295-316.

52 Lutz Raphael, 'Pluralities of National Socialist Ideology', in Visions of Community in Nazi Germany: Social Engineering and Private Lives, eds., M artina Steber and Bernhard Gotto (Oxford: Oxford University Press, 2014), 73-86.

${ }^{53}$ On the need to shift from 'institutionally-bound analysis' to culture in Nazi ideas of region, see Geoff Eley, 'Commentary: Thoughts on Nazism's Spatial Imaginary', in Heimat, Region, and Empire, eds., Szejnmann and Umbach, 252-267.
} 
propaganda, as one Nazi pedagogue insisted, they should only teach children history rooted in spaces of 'national destiny.' Historical views based on 'Heimat', he argued, were the products of a 'liberal' world-view that must be scrapped. ${ }^{54}$ While publication of regional Heimat journals had exploded in the Weimar years, the regime drastically slashed them by around 40\% from 1933 to 1940. (Figure 3) Focus on regional Heimatkunde decreased significantly, with a parallel decline in publication of Heimat books. ${ }^{55}$ Use of regionalism in propaganda did prove particularly attractive to Gauleiter seeking to consolidate their footing within the new regime. ${ }^{56}$ As Núñez Seixas points out, the Nazi regime and other fascist regimes were skilled improvisers, that were more than willing to appropriate regionalism when useful. ${ }^{57}$ Though Hitler praised how technologies of movement would level regional cultural differences and declared they would rip federalism from the face of Germany, the Nazi state was hardly the most centralized dictatorship. ${ }^{58}$ Nor did H eimat enthusiasts publicly resist attempts to forbid J ewish members from their societies or offer any open objection to destruction of sites of Jewish cultural heritage within the region. Little evidence, moreover, suggests that regionalist's support of Nazism was lower than that of German society at large.

Yet, the regime's ambivalent approach to regionalism was apparent in a number of areas, including in their 'coordination' of the regionalist Weimar-era journals. The Rheinische Heimatblätter, published in the Weimar years by a collection of Heimat societies, offers a telling example. After 1933, the largely antiquarian and unpolitical journal was removed from the control of Heimat societies, had the term Heimat removed from its title and was placed under the Kampfbund für deutsche Kultur. Non-political regional pieces were scaled back dramatically, with the new publication split approximately three ways between non-regional national propaganda, regional propaganda pieces, and less overtly political regional articles. Several new themes became salient, including the military history of the Rhineland, the artificial nature of the western national border, ancient Germanic histories, denunciations of separatism, and emphasis on regional economic

\footnotetext{
${ }^{54}$ Dietrich Klagges, Geschichtsunterricht als nationalpolitische Erziehung (Frankfurt: M oritz Diesterweg, 1937), 165-167.

${ }^{55}$ Julia Faehndrich, 'Entstehung und Aufstieg des Heimatbuchs', in Das Heimatbuch: Geschichte, M ethodik, Wirkung, ed., M atthias Beer (Göttingen: V \& R Unipress, 2010), 62-72.

${ }^{56}$ See M artina Steber, 'Regions and National Socialist Ideology', in Heimat, Region, and Empire, eds., Szejnmann and Umbach, 25-42; Catherine Epstein, 'Germanization in the Warthegau: Germans, Jews and Poles in the Making of a "German" Gau', in Ibid, 93-111

${ }^{57}$ See chapter by Núñez Seixas. See also Kay Dohnke, Norbert Hopster and Jan Wirrer, eds., Niederdeutsch im Nationalsozialismus. Studien zur Rolle regionaler Kultur im Faschismus (Hildesheim: Georg Olms, 1994). ${ }^{58}$ Jeremy Noakes, 'Federalism in the Nazi State', in German Federalism: Past, Present, Future, ed., M aiken Umbach (Basingstroke: Palgrave Macmillan, 2002), 113-145; M ichael Kissener, 'Nationalsozialismus und Widerstand', in Heimat. Konstanten und Wandel im 19./20. Jahrhundert, ed., Katharina Weigand (M unich: Deutscher Alpenverein, 1997), 210-211.
} 
output. ${ }^{59}$ As one large-printed quotation in the journal maintained: 'Work is Heimat!' ${ }^{60}$ Regionalism was to be stripped of its inwardness and funnelled into national expansion. In turn, the Nazis used the publication to declare that the Rhineland must 'radiate' German cultural influence across the western border, reject 'petty statism', embrace its 'war front legacy,' and turn its focus to the plight of Germans in the East. ${ }^{61}$ The theme of a national community of struggle, absent in the pre-1933 publication, saturated the periodical after the seizure of power.

Nazi propaganda in other regions illustrated a similar emphasis on eliminating regionalism's inward focus. As a propaganda book on Baden as a 'national borderland' maintained: 'we cannot think of our narrow Heimat Baden anymore without immediately thinking of the broader Empire.' The volume continued by emphasizing the crucial nature of regional labour in serving the nation. ${ }^{62}$ In a speech on his own 'Heimat' of Austria, Hitler argued for the irrelevance of a small space without it becoming part of a broader space. ${ }^{63}$ Attempts to invert regionalism outward could also be seen in a 1937 work on Alemannic culture which emphasized how their regional culture extended into Switzerland, justifying future action in 'forcing the Swiss to their knees'. ${ }^{64}$ The regime's visions of uprooting and resettling millions of Germans in the East illustrated perhaps the most patent disinterest in maintaining regional rootedness and likely informed its penchant for an abstract and generic regionalism in propaganda. ${ }^{65}$

The German declaration of war in 1939 altered the use of regionalism in propaganda, with greater emphasis on the cultural links between German regions and their newly conquered neighbours. In regionalist publications in the Rhineland, for example, the regime emphasized the cultural links with the Netherlands, Belgium, Alsace, and Luxembourg, while holding a 'GermanFlemish' cultural festival in the region. ${ }^{66}$ As Joep Leersen demonstrates, the Nazis particularly engaged with Frisian and Flemish culture in the Low Countries to promote a notion of their Germanness ${ }^{67}$. After the annexation of Austria, while subverting the Austrian national idea, the regime reframed Austrian regions as German ones, keeping most historical regional territorial

\footnotetext{
${ }^{59}$ These themes can be seen extensively from 1933 to the outbreak of the war in volumes 10-16 of the Rheinische Blätter.

${ }^{60}$ Heinrich Lersch, Rheinische Blätter 19, Nr.10 (October 1942): 295.

${ }^{61}$ These themes were dominant from 1933 to 1939 in volumes 10-16. On the need of regionalists to make German will 'radiate' beyond the national border, see Robert Brandes, 'Der Kampfbund im Rheinland', Rheinische Blätter 10, Nr.10 (October 1933): 909-912.

62 Oberstarbeitsführer Helff, ed., Grenzland Baden (Karlsruhe: C.F. Müller, 1936), 28.

${ }^{63}$ Ado If Hitler, 'M eine eigene Heimat', re-printed in Jürgen Liebig, ed., Heimat deine Heimat. Ein Lesebuch (Darmstadt: Luchterhand, 1982), 71-72.

${ }^{64}$ Jakob Schaffner, 'Rings um die alemannische Kulturtagung', in Alemannenland, ed., Franz Kerber (Stuttgart: Engelhorn, 1937), 28-31.

${ }^{65}$ See Applegate, Nation of Provincials, 197-227; Storm, Culture of Regionalism, 261-282.

${ }^{66}$ Rheinische Blätter volumes 17 to 20, published from 1940 to 1943. On the German-Flemish cultural festival, see vol.18, nr.7.

${ }^{67}$ See chapter by Leerssen.
} 
boundaries. At the same time, within Germany, the war deeply challenged citizen's connection to their Heimat, uprooting them to an unprecedented extent. As the anti-regime cleric, Alfred Delp, argued in a 1940 sermon on the Heimat concept, Heimat receded as they became a people on the road in 'war trips,' 'work trips,' and 'settlement trips.' 68 The homesickness of soldiers particularly became a problem, while, as with other states, the need to funnel regional resources and sentiments into the war effort proved essential. ${ }^{69}$ The regime's depiction of itself as the saviour of the Heimat proved increasingly difficult to reconcile with growing images of ravaged cities. M eanwhile, as recent work on mass evacuations have illustrated, the Nazi regime made little attempt to keep citizens near their local places of home-creating an unusual site of tension between citizens and the regime. ${ }^{70} \mathrm{In}$ the ruins of defeat, fears that 'Heimat was no more' emerged as a strong source of anxiety.

\section{Redemptive Regionalism in the Aftermath}

In 1947, a report from Cologne noted the astonishing 'wild-growing Heimat cultural activities' in the ruins. Amidst the rubble, West Germans founded a surprising profusion of regional Heimat societies and publications, wrote a flood of dialect poetry reflecting on lost local worlds and held frequent Heimat evenings to cope with life in the ruins. Regionalists revived a range of Heimat traditions to much fanfare, while holding special regionalists events described as gathering energies for reconstruction. ${ }^{11}$ While Hanseatic Heimat enthusiasts on the northern coast noted how Heimat feeling exceeded that of times of 'blossom,' others, including a regionalist in the southwest and a historian in Bavaria remarked how 'Heimat' reached greater heights amidst collapse than in times of peace and how disaster triggered 'a new animation of Heimat thoughts.' ${ }^{72}$ Throughout the West, scores of ephemeral regional journals circulated, many published samizdat, replaced after 1949 by more firmly established successors. Heimat books, as historians of the press have remarked, also had an unusually high presence in the publications of the new Federal Republic. ${ }^{73}$

\footnotetext{
${ }^{68}$ Alfred Delp, 'Heimat', in Alfred Delp, Gesammelte Schriften. Band II: Philosophische Schriften, ed., Roman Bleistein (Frankfurt: Knecht, 1983), 249-269.

${ }^{69}$ On the example of the Soviet Union, see Lisa Kirschenbaum, '"Our City, Our Hearths, Our Families": Local Loyalties and Private Life in Soviet World War II Propaganda', Slavic Review 59, no.4 (Winter 2008): 828-847. 70 Julie Torrie, 'For Their Own Good': Civilian Evacuations in Germany and France, 1939-1945 (New York: Berghahn, 2010).

${ }^{71}$ Statistischen Amt der Stadt Köln, Verwaltungsbericht der Stadt Köln, 1945/ 47 (Cologne: Stadt Köln, 1947), 54-55.

${ }^{72} \mathrm{M}$ ax Brauer, 'Rede am 22. November 1946', in Nüchternen Sinnes und Heissen Herzens: Reden und Ansprachen, Max Brauer (Hamburg: Auerdruck, 1956), 24-25; Otto Feger, Konstanz: Aus der Vergangenheit einer alten Stadt (Konstanz: Curt Weller, 1947), 11; Celia Applegate, 'Senses of Place', in The Oxford Handbook of Modern German History, ed. Helmut Walser Smith (Oxford: Oxford University Press, 2011), 63.

${ }^{73}$ Kurt Koszyk, 'Presse und Pressekonzentration in den 50er Jahren', in Modernisierung im Wiederaufbau: die westdeutsche Gesellschaft der 50er Jahre, eds., Axel Schildt and Arnold Sywottek (Bonn: J.H.W. Dietz, 1993), 441.
} 
This regional turn in the West after 1945 has been much neglected in the scholarship on German regionalism. While Celia Applegate and Jörg Arnold have pointed to the strong early postwar attraction to Heimat in the West, the stubborn myth of Heimat as taboo in the aftermath has persisted. ${ }^{74}$ Yet, in examining thousands of sources on early post-war regionalism from a range of authors, places, and media, we find not only numerous references to the Heimat idea reaching unprecedented heights, we also find virtually no reference to it as tainted. ${ }^{75}$ This changed only in the 1960s, when a combination of generational, economic, and political changes resulted in a contested turn against regionalism and Heimat. In the immediate post-war years, four primary factors informed the turn to regionalism. The first was the elimination of the nation-state as an actor and resulting recourse to regional communities in reconstruction. Heimat secondly acted as a site of imagined protection, familiarity, and orientation at a time of uncertainty. The third was the need for flexible sources of identity and a site from which to rethink the national idea. While national identities proved burdened, regions offered alternative identities and a foundation from which to imagine a new federalist national idea. The fourth factor was the sheer extent of dislocation and destruction, with resulting fears of lost Heimat triggering a form of compensatory regionalism. While the physical built environment of Heimat had often been destroyed, many discussed how reviving non-material regional cultural practices could compensate. As one regionalist journal maintained, the inability to reconstruct the lost physical landscapes of Heimat made it all the more important to preserve regional cultural practices. ${ }^{76}$

\footnotetext{
${ }^{74}$ Applegate, Nation of Provincials, 228-246; Jörg Arnold, The Allied Air War and Urban M emory: The Legacy of Strategic Bombing in Germany (Cambridge: Cambridge University Press, 2011).

${ }^{75}$ Jeremy DeWaal, Redemptive Geographies: Heimat and Democratization in West Germany, 1945-1990 (In Preparation)

${ }^{76}$ Untitled excerpts in Alt und Neu-Köln (1946), 2.
} 
While West Germans could return home, revive regionalism, and fashion new regional identities, this was impossible for German expellees from former eastern regions. Expellees engaged in regional cultural activities, but only in a dispersed fashion outside their region. Meanwhile, in the Soviet Zone, Germans had clear attraction to regional cultural activities, though the occupiers and the East German state tapped down on independent Heimat activities. The resulting crack down deflated, but did not eliminate the regionalist movement. The new regime did eliminate the federal states, and over time, appropriated a new de-localized Heimat idea to promote identification with the state at large, while depicting the West as the imperialist abusers of the Heimat concept. M eanwhile, private ideas of Heimat in the dictatorship continued underneath the surface, while a host of regional cultural particularities could hardly be swept under the rug. ${ }^{77}$

While neither West nor East German regionalists abandoned German identities, the opposite was true in neighbouring Austria, where regionalists fundamentally abandoned previously contested notions of Austria's Germanness. The Heimat concept in post-war Austria, in turn, came to refer both to the nation and its regions, strictly separating the Austrian and German national ideas. ${ }^{78}$ Although the federalist structures of the First Austrian Republic were largely restored in the second Republic, Austrian regionalists enthusiastically embraced a small-state national idea after 1945. While the Austrian nation had gone from monarchy to republic and German dictatorship, in a new republic its historically continuous regions offered a stable cultural reference point. ${ }^{79}$ Austrian federalism was less decentralized than in the Federal Republic, while Austrian national identity was infinitely less burdened, making regional identities less essential as a site of alternative identification. Austrian regionalism also proved unique in the degree to which it politically revolved around tensions between the politically left metropolitan centre of Vienna and the conservative rural regions.

The most precarious and politicized ethnic German regionalists were unquestionably the millions of expellees from the East, whose regionalism continued without a region. While expellees in the German Democratic Republic (GDR) were forbidden to engage in regional cultural activities, expellees in the west founded a range of regional societies to preserve regional cultures and engage in politics. M eanwhile, former eastern regions became home to new Polish populations, many of whom had themselves been displaced from eastern Polish areas annexed by the Soviet Union. New Polish inhabitants, often having suffered greatly at the hands of Germans, sought to forge Polish narratives for new regions that erased German histories that went back to the Late Middle Ages. An

\footnotetext{
77 Jan Palmowski, Inventing a Socialist Nation: Heimat and the Politics of Everyday Life in the GDR, 1945- 1990 (Cambridge: Cambridge University Press, 2009); Schaarschmidt, Regionalkultur.

${ }^{78}$ Reinhard Johler, 'Die Wissenschaft der Heimat' in Heimat, ed., Weigand, 91.

${ }^{79}$ Stourzh, Vom Reich zur Republik, 58, 83.
} 
odd alliance of Polish nationalists, communists, and Catholic clergy cooperated in this process, though homesick tourism of German expellees later on triggered memories of their German history. ${ }^{80}$ Expellees in West German cities sought to preserve eastern German regional cultures in cultural sponsorships (Patenschaften) taken up by West German cities for eastern counterparts. Such places also frequently served as sites for annual expellee reunions. A decade after the founding of the West German state, at least 296 such cultural sponsorship had been created. ${ }^{81}$ Sudeten Germans particularly used the areas along the Czech border as a surrogate space for regionalist activities, unintentionally intensifying, as Yuliya Komska has demonstrated, the visibility of the iron curtain. ${ }^{82}$ Annual Heimat meetings, including on the so-called expellee 'Day of Heimat' offered a unique opportunity for regional cultural performances, often used to teach a new generation of children about eastern German cultures, combined with both private reunion and political speeches. (Figure 4) The ability to preserve eastern regional cultures as lived cultures, however, proved a constant source of anxiety.

While expellees were unable to return to their native regions, regional Heimat offered West Germans a site of imagined new beginnings. While some scholarship has argued that post-war Heimat was about tending to a sense of regional victimhood ${ }^{83}$, it was also in many ways about a search for recovery. Throughout regionalist discourses, the words 'life-affirmation' and 'Heimat' were evoked in conjunction to a notable degree. As the author Wolfgang Borchert argued, for him and his fellow Hamburg locals, their Heimat represented 'more than a pile of stones,' but rather their 'will to exist. ${ }^{84} \mathrm{~A}$ Badener regionalist similarly argued that, after the war, they could begin anew by 'holding together on the small bit of earth that is left to us, from the earth of the Heimat, in a small circle of the Badenese land and people.' ${ }^{85}$

In West Germany, regionalism became useful for imagining a decentralized federalist system. As one regionalists from the Southwest argued: 'within the reach of the Heimat-like parliament,' citizens found a comprehensible realm of democratic participation, while, by contrast, 'the germ of dictatorship' lied within the 'herd that has the ambition to be ever more numerous,

\footnotetext{
${ }^{80}$ Andrew Demshuk, 'Reinscribing Schlesien as Śląsk: Memory and Mythology in a Postwar German-Polish Borderland', History \& M emory 24, Nr.1 (Spring/Summer 2012): 39-86.

${ }^{81}$ Bundesarchiv B 234, Nr. 634, BdV, Liste I: Bestehende west-ostdeutsche kommunale und Landespatenschaften, 1961.

82 Yuliya Komska, The Icon Curtain: The Cold War's Quiet Border (Chicago: University of Chicago Press, 2015).

${ }^{83}$ Alon Confino, Germany as a Culture of Remembrance: Promises and Limits of Writing History (Chapel Hill: University of North Carolina Press, 2006).

${ }^{84}$ Wolfgang Borchert, 'In Hamburg', in Lieder und Sprüche auf Hamburg, ed. Paul Neumann (Hamburg: Hans Christians, 1960), 77.

${ }^{85}$ Leo Wohleb, 'Rede', February 24, 1946, in Humanist und Politiker: Leo Wohleb, eds. Paul Ludwig-Weinacht and Hans M aier (Heidelberg: Kerle, 1969), 171.
} 
ever more unitary, ever more powerful.' ${ }^{86}$ Rather than assuming either a nationalist or separatist idea of region, West German regionalists after 1945 frequently argued for region as a force that restrained and therein served the nation. As the Badenese regionalist, Max Picard argued: 'It is...possible that the individual in Germany can find themselves when they take themselves out of the vague grandiose state and bring themselves into the concreteness of the small state.' ${ }^{87} \mathrm{Few}$ sought to toss German identity overboard and only a small minority argued for regional autonomy. The Swabian regionalist, Otto Feger, was among this group in arguing for an autonomous 'SwabianAlemannic democracy.' He proved more representative, however, in arguing that regional traditions of 'democracy' and western-orientations could aide democratization and European unity. ${ }^{88}$

The Western allies strongly supported the creation of a federalist system, ratified in 1949. Though more decentralized than neighbouring Austria, the state of Bavaria refused to ratify the basic law as a protest for even more decentralization. Separatism never gained a significant following, though the Bavaria Party, which included both separatists and advocates of extreme federalism, won around $20 \%$ of the regional vote in the state in the first federal elections. In the new republic, federal states were given significant authority in education and culture and were represented within a new Bundesrat that bore substantially more power than the Reichsrat of the Weimar Republic. Article 30 of the new basic law reserved all rights not given to the federal government to the regional states.

The allies directed the new republic to redraw its regional state borders, which the occupiers had provisionally drawn. $M$ any regionalists viewed this as a unique opportunity to forge regional states drawn descriptively according to regional identities. While the federal map would never be redrawn, attempts to envision the project proved revealing. The provision of the constitution which included regional belonging among the factors to be considered in redrawing the map triggered the establishment of a large parliamentary-scholarly apparatus to discover where such spaces lied. The project revealed fundamental disparateness in popular imaginings of regional community. A host of factors could inform territorial imaginings of region, including dialect borders, geographic features, ritual traditions, confession, tribe, orientation to urban centres, or past territorial states, but none created universally shared cognitive maps of region. This phenomenon parallels both Kabatek and Hopkin's observations that dialect spaces and ecotypes of folkloric practices both deeply influenced regional identities but often did not neatly correspond to borders of imagined regional belonging. ${ }^{89}$

\footnotetext{
${ }^{86}$ Bundesarchiv B 144 Nr. 253, Walter von Cube, 'Um die Selbständigkeit des Landes Baden,' July 1, 1951, in Circulatory, 'Vom See bis des M aines Strand.'

${ }^{87} \mathrm{M}$ ax Picard, Hitler in uns Selbst (Zürich: Eugen Rentsch, 1946). 262.

88 Otto Feger, Schwäbisch-Alemannische Demokratie (Konstanz: Curt Weller, 1946).

${ }^{89}$ See chapters of Hopkin and Kabatek.
} 
In contrast to nations, which underwent long and often violent histories to define their geographic contours, more highly divergent cognitive maps of region circulated underneath the surface.

Federalist enthusiasm and notions of region as restraining nationalism were not universally shared, particularly by many expellees. As one Silesian argued in an expellee newspaper, West Germans were excessively focused on their own regions and should 'be German and not Bavarian or Hessian, or God knows what else...' ${ }^{90}$ Loss of home based on national belonging, experience of expulsion, and desire for recognition of their plight by maintaining national territorial claims all informed a more nation-affirming vision of region among many expellees. While expellee Heimat books were saturated with assertions of their region's Germanness, expellee political leaders emphasized their region's critical role in the nation and argued for greater national spirit among their fellow westerners. ${ }^{91}$

Though visions of a federalism of 'Heimat states' never bore fruit, democratic regionalists had more success in re-shaping regional identities. Vaguely-defined ideas of 'democracy,' 'Europeanness' and 'world-openness' as regional values emerged in discourses in a number of territories. Ideas of regional 'Europeanness' could particularly be seen in western border regions and maritime areas, which rapidly abandoned former nationalist regional narratives. In the Rhineland, the trope of the 'Watch on the Rhine' was nowhere to be found, while the Hanseatic cities, known as 'gates to the world,' abandoned narratives of the gate as an exit point of German power. Evoking regional Roman and medieval histories, Rhenish regionalists emphasized their role as a 'world-open bridge' to Western Europe, while Hanseatic localists defined their local 'gates' as rooted in a 'Hanseatic world-openness' and international reconciliation. Badenese regionalists like Reinhold Schneider similarly argued that his region was an open 'hall on the Rhine' and gate to the West. ${ }^{92}$

Articulation of vague ideas of 'democracy' as an alleged regional value became prevalent by the late 1940s, reflected in ideas such as 'Badenese democracy,' 'Cologne democracy,' 'SwabianAlemannic democracy,' and 'Hanseatic democracy.' While Hanseatic citizens drew on their long histories as city republics, Cologners drew on histories going back to their medieval 'guild democracy.' Regional histories of the 1848 revolutions particularly became useful, evoked with alacrity amongst regionalists in Baden, Swabia, and the Rhineland. Histories of regional anti-Prussian sentiment also proved instrumental, with Prussian militarism, rigidity and class hierarchies serving as a foil for new regional identities. Reinvention of regional traditions further offered a useful tool.

\footnotetext{
${ }^{90}$ Bundesarchiv B 234, Nr. 626, 'Polnische sorgen um die Oder-Neiße-Linie', Ost-West-Kurier, October 22-28, 1949.

${ }^{91}$ Ulrike Frede, '“Unsere Heimat war deutsch!"', in Heimatbuch, ed., Beer, 179-202.

${ }^{92}$ Heimatbund Badenerland, Baden als Bundesland (Waldkirch: Waldkircher, 1955), 28.
} 
Rhinelander, for example, advanced notions of Carnival as a regional democratic tradition and magnified historic practices of expressing anti-Prussian sentiment in the tradition. ${ }^{93}$

Articulations of democracy and Europeanness as alleged regional values were by no means without their pitfalls. For one, they aggravated failures to come to grips with the regional Nazi past. Though regionalists seldom argued directly that such values lessened guilt, the implication undoubtedly reinforced their appeal. Nor did they suddenly transform regionalists into adept practitioners or democracy, with many undemocratic continuities persisting in the early Federal Republic. At the same time, greater identification with democracy and European unification on a local and regional level did aide in disbanding the dangerous notion that democracy was a foreign body.

\section{Contested Re-valuations}

Leaving the world of rubble behind them, West Germans,Austrians, and other Western europeans experienced tremendous economic growth, followed by a series of political, cultural and generational changes that would alter attitudes toward regionalism. In the short term, economic growth harmonized with regionalist desires, facilitating reconstruction and domestic nesting, while providing additional resources for regional cultural activities. Throughout this period, 'Heimat films' also reached their height in West Germany and Austria, depicting the 'wholesome' rural life, often situated in mountainous bucolic landscapes. While historians have debated whether such films were anti-modern and escapist or about negotiation between modernity and rootedness, they often represented a generic regionalism that was less representative of popular interest in Heimat. ${ }^{94}$ Popular desires for Heimat after the war were for places anything but generic, and, as one Lower Saxon Heimat enthusiast argued, film often misrepresented experience of Heimat. ${ }^{95}$

Over the long term, economic growth and reconstruction reduced both the fears of lost Heimat and compensatory needs for local communities which had fuelled regionalism. By the end of the 1950s, the Heimat concept also became increasingly intertwined in heated political debates over expellee claims to the former East. While emphasis on an expellee 'right to Heimat' seemed more reasonable in the early post-war years, passage of time, increased integration, the unlikelihood of return, and desires for rapproachment with the East brought the Heimat concept increasingly into heated Cold War debates. These developments combined in the 1960s with generational changes that resulted in a cultural turn against regionalism.

\footnotetext{
${ }^{93}$ DeWaal, 'Reinvention of Tradition', 523-528.

${ }^{94}$ On Heimat films as negotiating between modernity and rootedness, see Johannes von M oltke, No Place Like Home: Locations of Heimat in German Cinema (Berkeley: University of California Press, 2005).

${ }^{95}$ Herbert Röhrig, 'Der Heimatgedanke in unserer Zeit', Jahrbuch Deutscher Heimatbund (1959): 29-32.
} 
A new youth generation differed from their parents in coming of age at a time of stability, more intact communities, and absence of forced movement, with their perception of Heimat increasingly coloured by its use in rancorous expellee politics. They also reacted against their parent generation's preoccupation with local rootedness. As one author argued, she had been 'fattened up' with 'Heimat' and Swabian regionalism in her youth, leading her to grow tired of home and craving foreign places. ${ }^{96} \mathrm{M}$ any responded to expellee's political wielding of Heimat against rapprochement by appropriating histories of its misuse in Nazi propaganda. As the author Gabriele Wohmann wrote in the mid-1960s, reflecting on expellee rhetoric: "Heimat Heimat Heimat," provoked sentimentalrecalcitrant impulses that do not allow peace without 'Heimat.' Displaying little knowledge of the concept's history, Wohmann claimed it had been on its death bed in the Weimar years until its great awakening under Nazism, when, so she claimed, the range of compound words with 'Heimat' had been formed. ${ }^{97}$ The 1960s further saw the elimination of 'Heimatkunde' as a school subject in most states, while anti-Heimat films and anti-Heimat literature emerged as artistic genres which depicted regional culture as largely backward, ruralist and regressive.

Regionalists societies by no means closed down in the 1960s, while the 1970s and 1980s saw contested regionalist revivals, with progressives playing a notable role. After a period of economic stagnation and disappointment over failed utopian visions of the 1960 s, regionalism came to the fore as a means of protesting environmental destruction, centralization and technocratic remaking of cities and local landscapes. ${ }^{98}$ Regionalism became a locus of new protest movements against centralized overhaul of cities that disregarded regionalist particularities and against environmental destruction of regional landscapes. The protests against the construction of a nuclear plant near the Badenese town of Wyhl illustrated the mobilization of both regional dialect and culture in protest against both environmental destruction and increasing feelings that citizens had become objects of centralized administration.

The growth of regionalism beginning in the mid-1970s hardly remained uncontested, with equation of Heimat with backwardness persisting. As the sociologist and scholar of regional culture, Hermann Bausinger noted in 1979, when using the Heimat concept, one still had to watch over one's shoulder. ${ }^{99}$ National re-unification in the 1990s would bring new developments to the movement, witnessing both the awakening of regionalist sentiments in the former GDR and the formal

\footnotetext{
${ }^{96} \mathrm{M}$ argarete Hannsmann, untitled contribution, in Literatur im Alemannischen Raum: Regionalismus und Dialekt, eds., Jochen Kelter and Peter Salomon (Freiburg: Dreisam, 1978), 46-47.

${ }^{97}$ Gabriele Wohmann, 'Wörter mit Temperatur', in Gegen den Tod: Stimmen deutscher Schriftsteller gegen die Atombombe, ed., Gudrun Ensslin (Stuttgart: cordeliers, 1964), 104-106.

${ }^{98}$ Wilfried von Bredow and Hans-Friedrich Foltin, Zwiespältige Zufluchten: Zur Renaissance des Heimatgefühls (Bonn: J.H.W. Dietz, 1981).

${ }^{99}$ Hermann Bausinger, 'Heimat und Identität', in Heimat und Identität: Probleme regionaler Kultur, ed., Konrad Köstlin (Neumünster: Karl Wachholtz, 1980), 22.
} 
recognition of Germany's eastern border. Given the passage of time, expellee cultural preservation, incapable of preserving regional cultures as 'lived' cultures, became increasingly limited to the realm of museums and cultural performances.

Throughout the latter half of the twentieth-century and into the present, immigration became an ever growing issue facing regionalists. Exclusionary forms of regionalism could easily be found, though more inclusively-minded regionalists advanced ideas of region that could embrace foreign immigrants. Some regionalist arguments for acceptance of immigrants drew on earlier narratives used to argue for embrace of expellees. As one Cologne localist argued in the early postwar years, their local natures were defined by their ability to embrace outsiders, stretching back to local integration of foreign artisans and Dutch refugees in centuries past, making expellee integration harmonious with local tradition. ${ }^{100}$ Decades later, as Italian and Greek immigrants began moving to the region, a Rhenish regionalist at the annual Heimat day argued that the Rhineland had a long history of immigration, and further pointed to their Roman history, noting how influx from the M editerranean historically enriched their regional culture. ${ }^{101}$ Such arguments provided only conceptual tools to promote greater inclusion. M ore recently, examples of the second generation of immigrant families laying claim to the culture of regionalism can be seen in figures such as cabaret of Django Asül performed in lower Bavarian dialect or in the Bernese dialect comics of Semih Yavsaner. Embrace of immigration remains central to the future viability of regionalism, which itself could arguably be harnessed as an integrative tool.

\section{Condusion}

The centrality of region to debates over German nationhood and the turbulence of twentiethcentury Central European history both provide a rich basis through which to illustrate the diverse political, national and cultural framings of regionalism. Popularized during a period of rapid modernization and nation building, regionalism proved a useful asset in negotiating change and the relationship of region and nation. The attraction of different political groups to the movement continued into the Weimar years, which simultaneously saw the further growth of nationalist regionalism. Though quite marginal, separatist movements in the Weimar years remind us that the relationship of nation and region was, in theory, never set in stone. The rise of Fascism displayed how National Socialism could appropriate regionalist language for propaganda, even if the regime displayed ambivalence toward the movement's inwardness.

Far from tainted in the aftermath of the war, regionalism emerged in the West as a useful asset, offering a site of flexible identity and federalist ideas of nation. M eanwhile, in the

\footnotetext{
${ }^{100}$ Adam Wrede, 'Um die Erhaltung Kölner Eigenart', Alt-Köln 2, 3 (M arch 1948): 9-10.

${ }^{101}$ Adolf Flecken, Gestaltung der Heimat nach rheinischer Eigenart (Neuss: GfB, 1966), 15-16.
} 
neighbouring GDR, the regionalist movement proved more muted under the control of the new regime which used Heimat selectively in state propaganda. By the 1960s, diverse forces resulted in a contested turn against regionalism in the West, followed by revivals in the 1970s and 1980s. In contemporary Germany, contested notions of Heimat as tainted have remained, as have progressive strains of regionalism-manifested at events like that of Rhenish dialect bands which came together before a group of 100,000 to sing in protest against violence against foreigners. ${ }^{102}$ The future development of regionalism and its engagement with questions of immigration, globalization, and raucous political developments remains to be seen.

Keywords: Heimat, political regionalism, cultural regionalism, German democratization, Regionalism in National Socialism, Regionalism in the Weimar Republic, Federalism, German Regionalism, Austrian Regionalism, Swiss regionalism.

\section{ABSTRACT}

The history of regionalism in German-speaking Europe reflects the tremendously flexible nature of the regionalist phenomenon, its political framings, relationships to nation, urban vs. rural context and its geographic reference points. The relationship of region to nation ranged from nationaffirming regionalism to separatism or popular post-1945 notions of regionalism as serving the nation by decentring it. The initial boom of regionalism occurred in the1890s and continued with only brief interruption into the interwar years. National Socialism, while often described as either hostile or enthusiastic about regionalism, displayed divergent and pluralist attitudes toward the movement. The immediate post-war years saw a significant boom of regionalism in the West as a site of federalism and alternative "democratic" and "European" identities. The subsequent cultural turn against regionalism of the 1960s was followed again in the 1970s and 1980s with progressive regionalist revivals.

\section{FURTHER READING}

Applegate, Celia. A Nation of Provincials: The German Idea of Heimat (Berkeley: University of California Press, 1990).

Applegate, Celia. 'Senses of Place', in The Oxford Handbook of M odern German History, ed. Helmut Walser Smith (Oxford: Oxford University Press, 2011), 49-70.

Blackbourn, David and James Retallack, eds. Localism, Landscape, and the Ambiguities of Place: German-Speaking Central Europe, 1860-1930 (Toronto: University of Toronto Press, 2007).

${ }^{102}$ AG Arsch huh, ed., Arsch huh, Zäng ussenander! Gegen Rassismus und Neonazis (Cologne: Kiepenheuer \& Witsch, 1992). 
Green, Abigail. Fatherlands: State-Building and Nationhood in Nineteenth-Century Germany (Cambridge: Cambridge University Press, 2001).

Palmowski, Jan. Inventing a Socialist Nation: Heimat and the Politics of Everyday Life in the GDR, 1945- 1990 (Cambridge: Cambridge University Press, 2009).

Rollins, William. A Greener Vision of Home: Cultural Politics and Environmental Reform in the German Heimatschutz M ovement, 1904-1918 (Ann Arbor: University of M ichigan Press, 1997).

Umbach, Maiken and Bernd-Rüdiger Hüppauf, eds. Vernacular M odernism: Heimat, Globalization and the Built Environment (Stanford: Stanford University Press, 2005).

von M oltke, Johannes. No Place Like Home: Locations of Heimat in German Cinema (Berkeley: University of California Press, 2005). 


\section{FGURES}

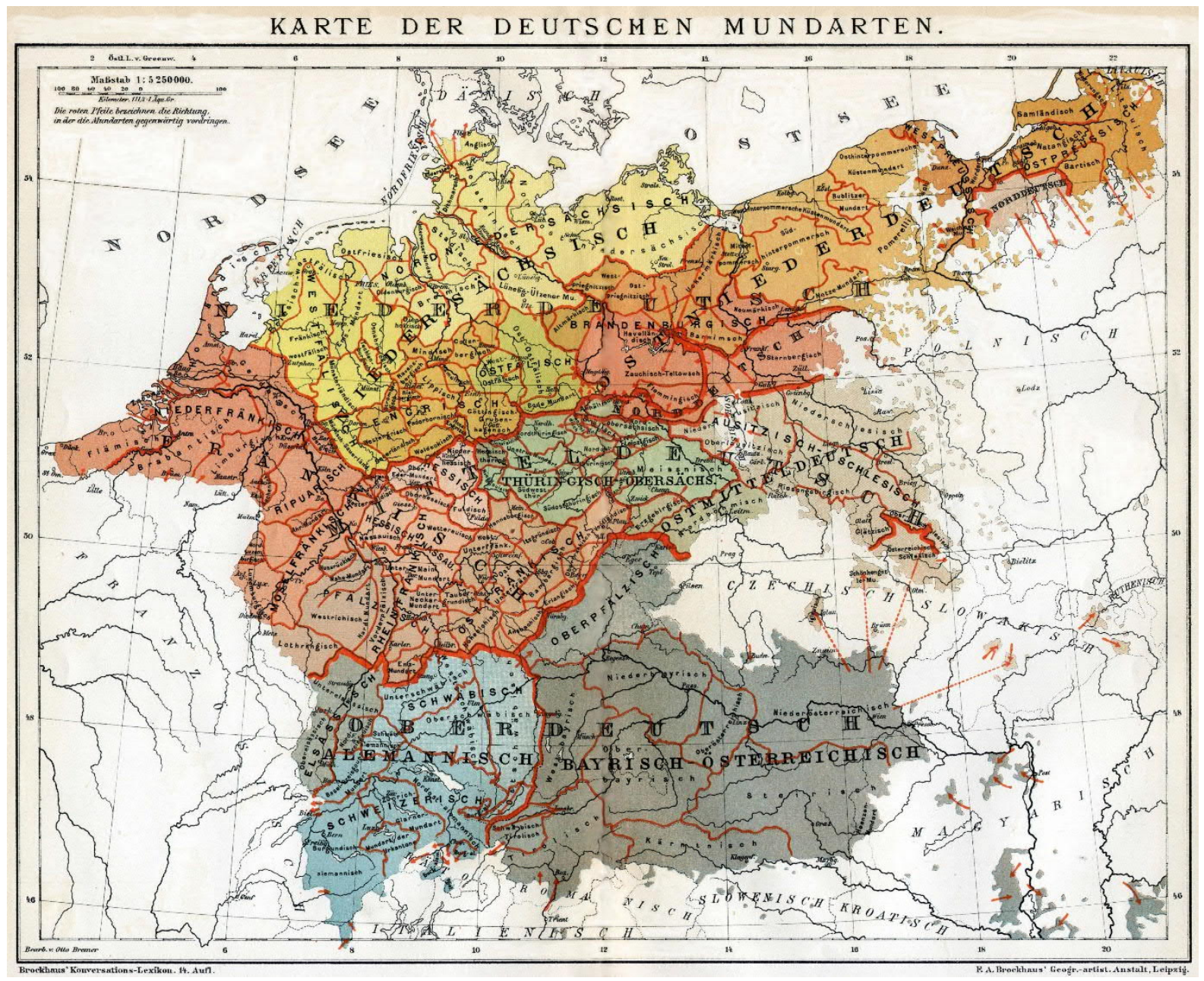

Figure 1. Map of approximated German dialect groupings (1894). Source: Brockhaus' Konversationslexikon, 14 ed., vol.5 (Leipzig: F.A. Brockhaus, 1894 ), p. 28a 


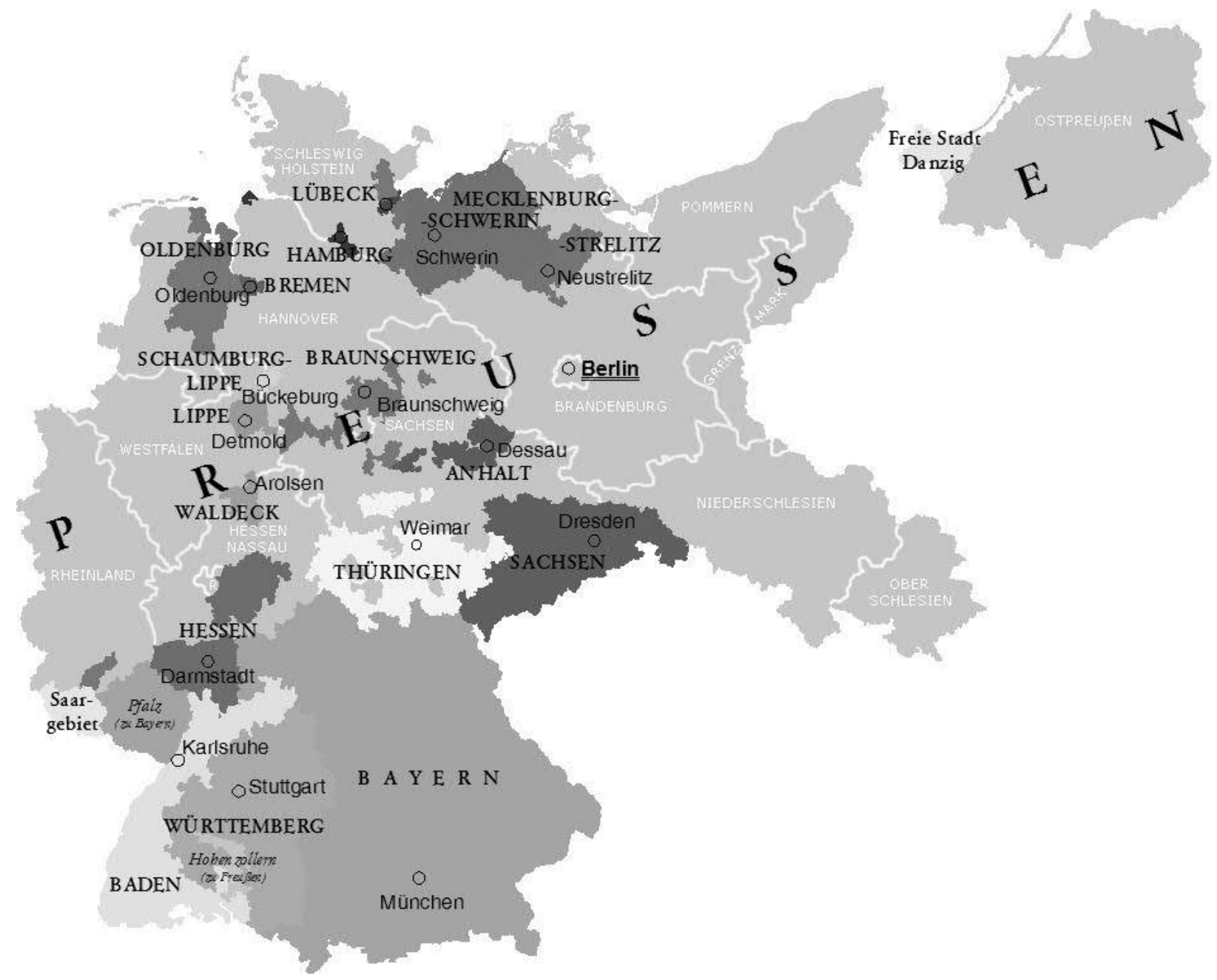

Figure 2. Map of the Federal States and Provinces of Prussia in the Weimar Republic in 1925. Source: Wikimedia Commons. 


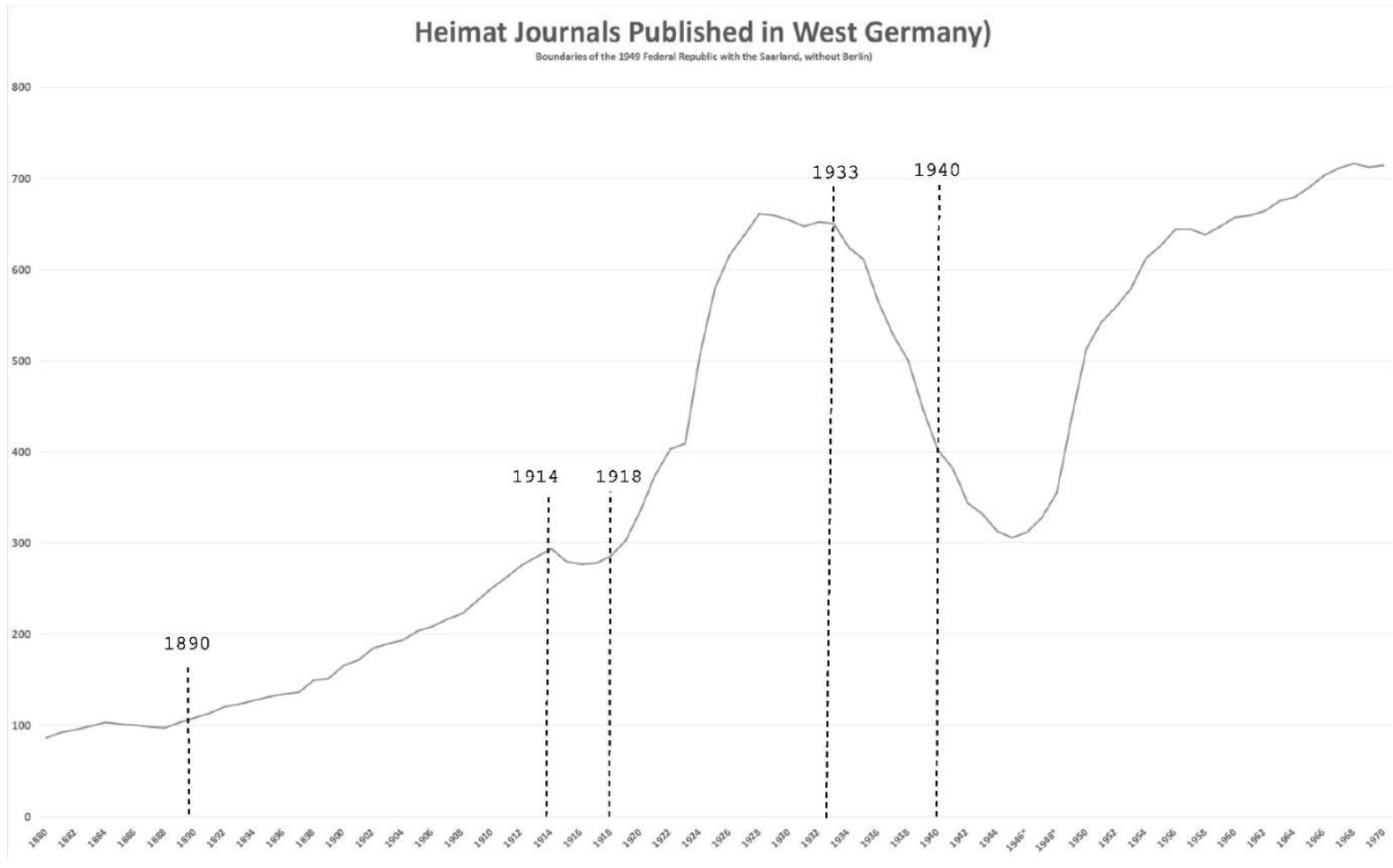

Figure 3. Heimat journal publication in the territories of West Germany (including the Saarland, excluding West Berlin) in the long twentieth century. Numbers compiled from an analysis of Rudi Mechthold's index of Heimat journals. *These numbers are based on publications from established presses and do not include many of the ephemeral publications, often in self publication, that frequently appeared in the early post-war years. Source: Rudi M echthold (ed.), Landesgeschichtliche Zeitschriften 1800-2009: Ein Verzeichnis deutschsprachiger landesgeschichtlicher und heimatkundlicher Zeitschriften, Zeitungsbeilagen und Schriftenreihen (Frankfurt: Vittorio Klostermann, 2011). 


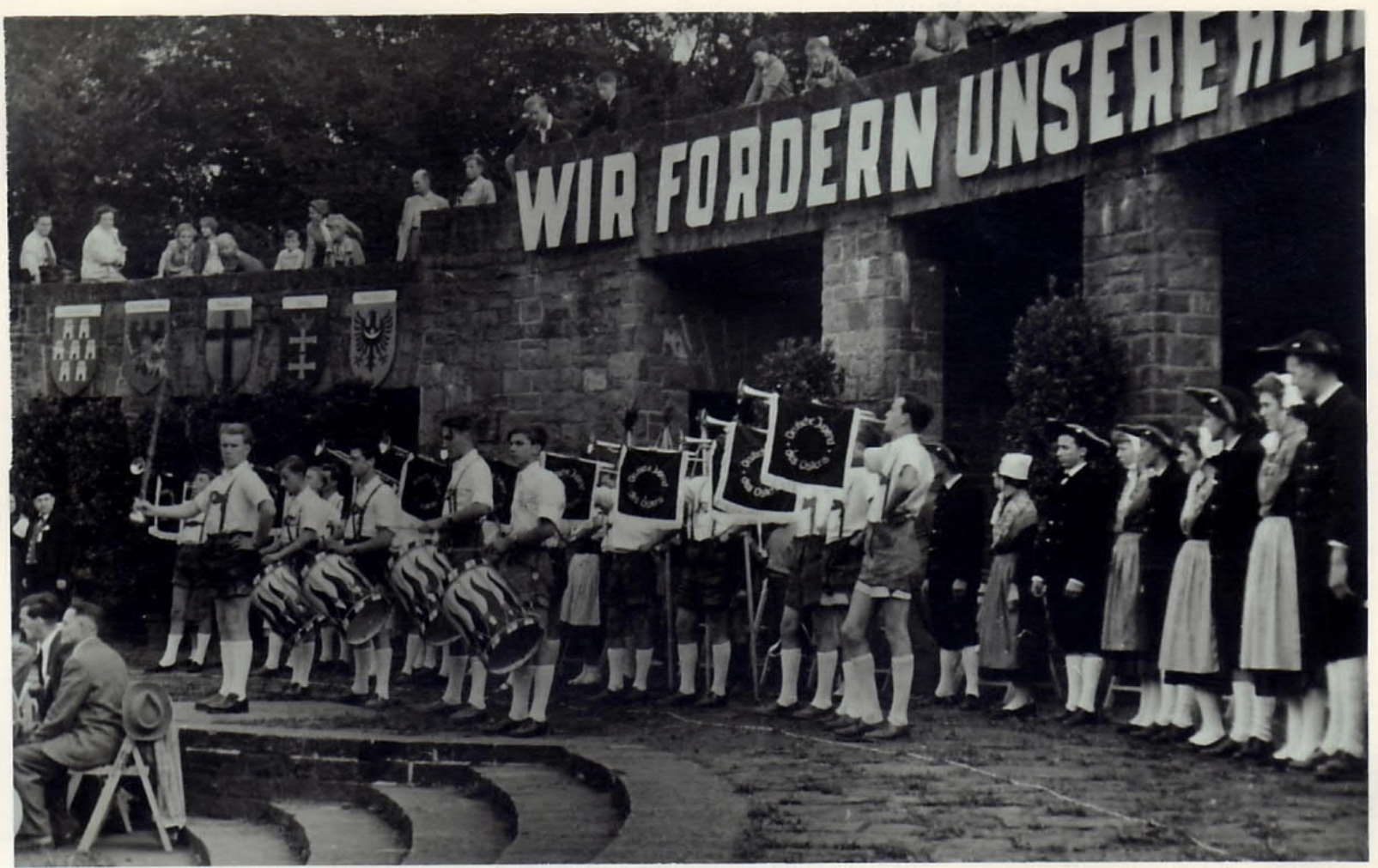

Figure 4. Observations of the expellee 'Day of Heimat' in Berlin 1955. Source: Private Collection of the Bund der Vertriebenen, Bonn. 